\title{
PENGARUH MODEL PEMBELAJARAN THINK PAIR SHARE (TPS) \\ DENGAN STRATEGI CROSSWORD PUZZLE TERHADAP CIVIC KNOWLEDGE PESERTA DIDIK PADA MATA PELAJARAN PENDIDIKAN PANCASILA DAN KEWARGANEGARAAN
}

\author{
${ }^{1}$ Cahyono \\ ${ }^{1}$ Universitas Pasundan \\ cahyono@unpas.ac.id
}

\begin{abstract}
ABSTRAK
Penelitian ini bertujuan untuk mengetahui adanya pengaruh model pembelajaran Think Pair Share (TPS) dengan strategi Crossword Puzzle terhadap Civic Knowledge peserta didik. Penelitian ini dilaksanakan di kelas XI SMA Negeri 3 Subang. Metode penelitian kuasi eksperimen, desain penelitian Nonequivalent Control Group Design. Sampel kelas XI IPA 1 kelas kontrol, kelas XI IPA 4 kelas eksperimen. Instrumen diolah menggunakan Software Minitab 17 for Windows. Berdasarkan hasil analisis data penelitian, diperoleh bahwa terdapat perbedaan yang signifikan antara kelas eksperimen dan kelas kontrol. Kesimpulan tersebut didasarkan pada hasil uji hipotesis dengan menggunakan Independent T-Test terhadap kedua nilai posttest. Hasilnya P-Value $<0,05$ yaitu $0,003<0,05$, serta terdapat pengaruh positif model pembelajaran TPS dengan strategi crossword puzzle dengan nilai P-Value $0,000<0,05$. Terdapat pengaruh model pembelajaran TPS dengan strategi crossword puzzle terhadap civic knowledge peserta didik pada mata pelajaran Pendidikan Pancasila dan Kewarganegaraan di Kelas XI SMA Negeri 3 Subang.
\end{abstract}

\section{Kata Kunci : Think Pair Share, Crossword Puzzle, Civic Knowledge}

\section{PENDAHULUAN}

Pendidikan dipersiapkan untuk seluruh lapisan masyarakat agar mereka dapat bertahan dengan tantangan-tantangan baru yang akan mereka hadapi sesuai dengan kemajuan dan kondisi zaman. Mata pelajaran pendidikan pancasila dan kewarganegaraan merupakan ilmu pengetahuan yang bertujuan membentuk diri berdasarkan ciri-ciri masyarakat Indonesia. Melalui mata pelajaran ini diharapkan mampu membawa masyarakat Indonesia menjadi warga negara memiliki kepribadian yang konsisten serta mampu mewujudkan nilai-nilai pancasila dalam menjalankan proses kehidupan. (Nuryani, 2017; 2)

Pendidikan pancasila dan kewarganegaraan (PPKn) merupakan salah satu mata pelajaran yang banyak menuntut pengetahuan kewarganegaraan, diantaranya terdapat 8 (delapan) ruang lingkup materi dalam pembelajaran PPKn yang harus dipahami oleh peserta didik yang secara umum meliputi aspek-aspek sebagai berikut: 1 . Persatuan dan Kesatuan, 2. Norma Hukum dan Peraturan, 3. Hak Asasi Manusia (HAM), 4. Kebutuhan Warga Negara, 5. Konstitusi Negara, 6. Kekuasaan Politik, 7. Kedudukan Pancasila, dan 8. Globalisasi (Winarno, 2013: 29-30).

Mata pelajaran Pendidikan Pancasila dan Kewarganegaraan bertujuan untuk mempersiapkan warga Negara yang baik (to be good chitizenship). Melalui mata pelajaran PPKn ini, ada beberapa aspek 
kompetensi yang hendak dikembangkan yaitu mencakup pengetahuan kewarganegaraan (civic knownledge), keterampilan kewarganegaraan (civic skill), dan watak atau karakteristik kewarganegaraan (civic disposition) (Somantri, 2001: 299). Namun, kenyataanya menunjukkan bahwa tujuan pembelajaran PPKn belum tercapai sebagaimana yang diharapkan.

Dalam proses pembelajaran, hasil belajar merupakan suatu hal yang diperoleh atau dicapai peserta didik selama kegiatan pembelajaran di sekolah. Adapun hasil belajar dalam penelitian ini adalah kemampuan kognitif peserta didik, kemampuan kognitif peserta didik yang akan diteliti yaitu civic knowledge (pengetahuan kewarganegaraan), dimana peserta didik dapat mengetahui dan memahami serta mengaplikasikan materi yang diajarkan dalam berbagai aspek kehidupan setelah pelaksanaan proses pembelajaran. Branson (1999: 8) mengemukakan bahwa: "Pengetahuan kewarganegaraan (civic knowledge) berkaitan dengan kandungan atau apa yang seharusnya diketahui oleh warga Negara". Civic knowledge berkenaan dengan apa-apa yang perlu diketahui dan dipahami secara layak oleh warga Negara. Sejalan dengan pendapat di atas Wahidmurni, dkk. (2010: 18) menjelaskan bahwa seseorang dapat dikatakan telah berhasil dalam belajar jika mampu menunjukan adanya perubahan dalam dirinya. Perubahanperubahan tersebut diantranaya dari segi kemampuan berpikir, keterampilan, atau sikapnya terhadap suatu objek.

Salah satu model pembelajaran yang berkaitan dengan
PPKn sebagai upaya meningkatkan pengetahuan kewarganegaraan (civic knownledge) peserta didik yaitu model pembelajaran cooperative learning tipe think pair share. Think pair share merupakan suatu cara yang efektif untuk membuat variasi pola diskusi kelas (Arends 1997 dalam Komalasari, 2010: 64). Pola diskusi kelas yang diharapkan adalah dapat merangsang peserta didik untuk berpikir kritis, merespon dan menganalisis konsep materi yang diberikan oleh guru.

Think Pair Share (TPS) merupakan jenis pembelajaran kooperatif yang dirancang untuk mempengaruhi pola interaksi peserta didik. Model pembelajaran think pair share pertama kali dikembangkan oleh Frang Lyman dan rekan kerjanya di Universitas Maryland. Think pair share mampu mengubah asumsi bahwa metode resitasi dan diskusi perlu diselenggarakan dalam setting kelompok kelas secara keseluruhan. Think pair share memberikan kepada peserta didik waktu untuk berpikir dan merespons serta saling bantu satu sama lain (Aris Shoimin, 2014: 209).

Think pair share memiliki keunggulan yaitu memungkinkan peserta didik untuk merumuskan dan mengajukan pertanyaan-pertanyaan mengenai materi yang diajarkan dan memperoleh kesempatan untuk memikirkan materi yang diajarkan, peserta didik akan terlatih untuk bertukar pendapat dan pemikiran dengan temannya untuk mendapatkan kesepakatan dalam memecahkan masalah, peserta didik lebih aktif dalam pembelajaran karena menyelesaikan tugasnya dalam kelompok, peserta didik memperoleh kesempatan untuk mempresentasikan hasil diskusinya dengan seluruh peserta didik sehingga ide yang ada 
menyebar dan memungkinkan guru untuk lebih banyak memantau peserta didik dalam proses pembelajaran.

Fukus dalam penelitian yaitu bertujuan untuk memperoleh gambaran tentang pengaruh model pembelajaran think pair share dengan strategi crossword puzzle terhadap civic knowledge peserta didik pada mata pelajaran Pendidikan Pancasila dan Kewarganegaraan di Kelas XI SMA Negeri 3 Subang.

\section{A. KAJIAN TEORI}

\section{Tinjauan Pembelajaran Kooperatif}

Pembelajaran kooperatif (cooperative learning) merupakan bentuk pembelajaran dengan cara peserta didik belajar dan bekerja salam kelompok-kelompok kecil secara kolaboratif yang anggotanya terdiri dari empat sampai enam orang dengan struktur kelompok yang bersifat heterogen.

Pada hakikatnya cooperative learning sama dengan kerja kelompok. Oleh karena itu, banyak guru yang mengatakan tidak ada sesuatu yang aneh dalam cooperative learning karena mereka beranggapan telah biasa melakukan pembelajaran cooperative learning dalam bentuk belajar kelompok dikatakan cooperative learning, seperti dijelaskan Abdulhak dalam Rusman (2014: 203) bahwa "pembelajaran cooperative dilaksanakan melalui sharing proses Antara peserta belajar, sehingga dapat mewujudkan pemahaman bersama di antara peserta belajar itu sendiri”.

Dalam pembelajaran kooperatif, dua atau lebih individu saling tergantung satu sama lain untuk mencapai suatu tujuan bersama. Peserta didik yakin bahwa tujuan mereka akan tercapai jika peserta didik lainnya juga mencapai tujuan tersebut. Untuk itu setiap anggota kelompok bertanggung jawab atas keberhasilan kelompoknya. Siswa yang bekerja dalam situasi pembelajaran kooperatif didorong untuk bekerjasama pada suatu tugas bersama dan mereka harus mengkoordinasikan usahanya untuk menyelesaikan tugasnya. Slavin (2009: 4) menyatakan bahwa

"Pembelajaran kooperatif merujuk pada berbagai macam metode pengajaran di mana para peserta didik bekerja dalam kelompok kelompok kecil untuk saling membantu satu sama lainnya dalam mempelajari materi pelajaran. Dalam kelas kooperatif, para peserta didik diharapkan dapat saling membantu, saling mendiskusikan dan beragumentasi, untuk mengasah pengetahuan yang mereka kuasai saat itu dan menutup kesenjangan dalam pemahaman masing masing". Tujuan dibentuknya kelompok tersebut adalah untuk memberikan kesempatan kepada semua peserta didik untuk dapat terlibat secara aktif dalam proses berpikir dan kegiatan belajar. Selama bekerja dalam kelompok, tugas anggota kelompok adalah mencapai ketuntasan materi yang disajikan oleh guru, dan saling membantu teman sekelompoknya untuk mencapai ketuntasan belajar.

Johnson \& Johnson dalam bukunya Isjoni (2009: 17) mengemukakan bahwa "Cooperative learning adalah mengelompokkan peserta didik di dalam kelas ke dalam suatu kelompok kecil agar peserta didik dapatbekerja sama dengan 
kemampuan maksimal yang mereka miliki dan mempelajari satu sama lain dalam kelompok tersebut". Sejalan dengan pengertian tersebut Isjoni (2009:11) mengemukakan bahwa:

\section{Cooperative learning} merupakan strategi belajar dengan sejumlah peserta didik sebagai anggota kelompok kecil yang tingkat kemampuannya berbeda. Dalam menyelesaikan tugas kelompoknya, setiap peserta didik anggota kelompok harus saling bekerja sama dan saling membantu untuk memahami materi pelajaran. Dalam cooperative learning, belajar dikatakan belum selesai jika salah satu teman dalam kelompok belum menguasai bahan pelajaran.

Oleh karena itu, dengan dilaksanakannya cooperative learning diharapkan siswa dapat bekerjasama dengan peserta didik lain untuk mengerjakan tugas yang telah diberikan dan masing-masing peserta didik mempunyai tanggung jawab untuk memperoleh hasil yang telah ditargetkan dalam kelompok serta kerja peserta didik dapat lebih terarah karena tiap peserta didik sudah mempunyai peran masingmasing berkaitan dengan tugas yang telah diberikan.

Bebarapa pendapat di atas dapat ditarik kesimpulan bahwa model pembelajaran kooperatif adalah model pembelajaran dengan setting kelompok-kelompok kecil dengan memperhatikan keberagaman anggota kelompok sebagai wadah siswa bekerjasama dan memecahkan suatu masalah melalui interaksi sosial dengan teman sebayanya, memberikan kesempatan pada peserta didik untuk mempelajari sesuatu dengan baik pada waktu yang bersamaan dan ia menjadi narasumber bagi teman yang lain.
Jadi pembelajaran kooperatif merupakan model pebelajaran yang mengutamakan kerjasama diantara peserta didik untuk mencapai tujuan pembelajaran.

\section{Tinjauan Model Pembelajaran Kooperatif Think Pairs Share (TPS)}

Think pair share adalah suatu model pembelajaran kooperatif yang memberi peserta didik waktu untuk berfikir dan merespons serta saling bantu satu sama lain. Model ini memperkenalkan ide "waktu berfikir atau waktu tunggu" yang menjadi faktor kuat dalam meningkatkan kemampuan peserta didik dalam merespons pertanyaan. Pembelajaran kooperatif model think pair share ini relatif lebih sederhana karena tidak menyita waktu yang lama untuk mengatur tempat duduk ataupun mengelompokkan peserta didik. Pembelajaran ini melatih peserta didik untuk berani berpendapat dan menghargai pendapat teman (Cholis Sa'dijah, 2006).

Think pair share adalah strategi diskusi kooperatif yang dikembangkan oleh Frank Lyman dan koleganya dari Universitas Maryland pada tahun 1981. TPS mampu mengubah asumsi bahwa metode resitasi dan diskusi perlu diselenggarakan dalam setting kelompok kelas secara keseluruhan. TPS memberikan kepada peserta didik waktu untuk berfikir dan merespons serta saling bantu sama lain (Aris Shoimin, 2014: 209)

Think pair share memiliki prosedur yang secara eksplisit memberi peserta didik waktu untuk berfikir, menjawab, saling membantu satu sama lain. Dengan demikian, diharapkan peserta didik mampu bekerja sama, saling membutuhkan, 
dan saling bergantung pada kelompok kecil secara kooperatif.

Menurut Aris Shoimin (2014: 211) pembelajaran think pair share mempunyai beberapa komponen, sebagai berikut:

- Think (berpikir)

Pelaksanaan pembelajaran TPS diawali dari berpikir sendiri mengenai pemecahan suatu masalah. Tahap berfikir menuntut peserta didik untuk lebih tekun dalam belajar dan aktif mencari referensi agar lebih mudah dalam memecahkan masalah atau soal yang diberikan guru.

- Pair (berpasangan)

Setelah diawali dengan berpikir, peserta didik kemudian diminta untuk mendiskusikan hasil pemikirannya secara berpasangan. Tahap diskusi merupakan tahap menyatukan pendapat masing-masing peserta didik guna memperdalam pengetahuan mereka. Disukusi dapat mendorong siswa untuk aktif menyampaikan pendapat dan mendengarkan pendapat orang lain dalam kelompok serta mampu bekerja sama dengan orang lain.

- Share (berbagi)

Setelah mendiskusikan hasil pemikirannya, pasangan-pasangan peserta didik yang ada diminta untuk berbagi hasil pemikiran yang telah dibicarakan bersama pasangannya masing-masing kepada seluruh kelas. Tahap berbagi menuntut peserta didik untuk mampu mengungkapkan

pendapatnya secara bertanggung jawab, serta mampu mempertahankan pendapat yang telah disampaikannya.

\section{Langkah-Langkah model} pembelajaran Think pair share

Aris Shoimin (2014: 211) menyebutkan langkah-langkah model pembelajaran think pair share, sebagai berikut:

- Tahap satu, think (berpikir)

Pada tahap ini guru memberikan pertanyaan yang terkait dengan materi pelajaran. Proses TPS dimulai pada saat ini, yaitu guru mengemukakan pertanyaan yang menggalakan berpikir ke seluruh kelas. Pertanyaan ini hendaknya berupa pertanyaan terbuka yang memungkinkan dijawab berbagai macam jawaban.

- Tahap dua, pair (berpasangan) Pada tahap ini peserta didik berpikir secara individu. Guru meminta kepada siswa untuk berpasangan dan mulai memikirkan pertanyaan atau masalah yang diberikan guru dalam waktu tertentu. Lamanya waktu diterapkan berdasarkan pemahaman guru terhadap peserta didiknya, sifat pertanyaannya, dan jadwal pembelajaran. Siswa disarankan untuk menulis jawaban atau pemecahan masalah hasil pemikirannya. 
- Tahap tiga, share (berbagi)

Pada tahap ini peserta didik secara individu mewakili kelompok atau berdua maju bersama untuk melaporkan hasil diskusinya ke seluruh kelas. Pada tahap terakhir ini peserta didik seluruh kelas akan memperoleh keuntungan dalam bentuk mendengarkan berbagai ungkapan mengenai konsep yang sama dinyatakan dengan cara yang berbeda oleh individu yang berbeda.

\section{Kelebihan dan Kekurangan Model Pembelajaran Think Pair Share}

Aris Shoimin (2014: 211) menyebutkan ada beberapa kelebihan dan kekurangan model pembelajaran think pair share, sebagai berikut:

\section{Kelebihan}

○ TPS mudah diterapkan di berbagai jenjang pendidikan dan dalam setiap kesempatan.

- Menyediakan waktu berpikir untuk meningkatkan kualitas respons peserta didik.

- Peserta didik menjadi lebih aktif dalam berberpikir mengenai konsep dalam mata pelajaran.

- Peserta didik lebih memahami tentang konsep topik pelajaran selama diskusi.

- Peserta didik dapat belajar dari siswa lain.

○ Setiap siswa dalam kelompoknya mempunyai kesempatan untuk berbagi atau menyampaikan idenya.

\section{Kekurangan}

○ Banyak kelompok yang melapor dan perlu dimonitor.

- Lebih sedikit ide yang muncul.

- Jika ada perselisihan, tidak ada penengah.

\section{Tinjauan Strategi \\ Pembelajaran Crossword \\ Puzzle (Teka-Teki Silang)}

Proses pembelajaran akan berjalan dengan baik jika dilakukan dengan menggunakan cara-cara yang sesuai dengan kondisi dari peserta didik yang akan menerima pembelajaran tersebut. Guru sebagai penyalur ilmu pengetahuan kepada siswa dituntut agar bias menguasai dan memahami setiap siswanya. Karena dengan demikian seorang guru akan mudah menyampaikan ilmu kepada setiap peserta didiknya. Suatu pembelajaran dapat dikatakan dengan baik jika tujuan dari pembelajaran dapat tercapai. Dalam mencapai tujuan pembelajaran tersebut diperlukannya strategi pembelajaran yang tepat.

Strategi pembelajaran merupakan suatu garis-garis besar haluan untuk bertindak dalam usaha mencapai sasaran yang telah ditentukan (Syaiful Bahri, dkk, 2010: 5). Dalam hal pengajaran startegi itu amatlah diperlukan untuk mempermudah proses belajar mengajar sehingga peserta didik dapat dengan leluasa menyerap apa yang telah disampaikan oleh si pendidik. Syarif Bahri, dkk (2010: 5) menyebutkan ada empat strategi dasar dalam belajar yang meliputi hal-hal sebagai berikut:

a) Mengidentifikasikan serta menetapkan spesifikasi dan kualifikasi perubahan tingkah laku dan kepribadian anak didik sebagaimana yang diharapkan.

b) Memilih system pendekatan belajar mengajar berdasarkan aspirasi dan pandangan hidup masyarakat.

c) Memilih dan menetapkan prosedur, metode dan teknik belajar mengajar yang dianggap 
paling tepat dan efektif sehingga dapat memperoleh tujuan.

d) Menetapkan norma-norma dan batas minimal keberhasilan.

Dengan adanya suatu strategi dalam melaksanakan pembelajaran seorang guru akan mudah untuk memberikan pemahaman terhadap apa yang akan disampaikannya. Uraian tersebut memberikan kesimpulan bahwa strategi pembelajaran merupakan tolak ukur untuk mencapai tujuan pembelajaran yang akan dicapai.

\section{a. Pengertian Crossword Puzzle}

Crossword puzzle (teka-teki silang) merupakan salah satu strategi pembelajaran yang dikembangkan dari strategi active learning, strategi ini diklasifikasikan oleh Melvin Silberman pada active learning bagian keempat yaitu tentang "bagaimana agar belajar tidak lupa" (Lyna Rosyidah, 2012).

Crossword puzzle atau tekateki silang adalah sebuah teka-teki dalam kotak hitam dan putih yang berbentuk persegi yang tujuannya untuk menulis satu huruf di setiap persegi putih untuk membuat katakata dengan diberikan petunjuk pertanyaan. Kotak hitam menandakan dimana kata berakhir (Claire, 2010:6). Crossword puzzle sebagaimana yang kita ketahui sebagaimana yang kita ketahui sekarang, pertama kali dipublikasikan pada tanggal 21 Desember 1913 di Koran New York World. Penciptanya adalah Arthur Wynne, yang dirancang penuh pada bagian halaman hiburan yang disebut "Word-Cross". Hampir setiap abad, teka-teki silang merupakan salah satu teka-teki yang paling popular dikalangan anak-anak dan dewasa (Sugar dalam Ami Fatwayani, 2013).
Sejalan dengan penapat Zaini, dkk (2008: 71) crossword puzzle dapat digunakan sebagai strategi pembelajaran yang baik dan menyenangkan tanpa kehilangan esensi belajar yang sedang berlangsung. Bahkan strategi ini dapat melibatkan partisipasi peserta didik secara aktif sejak awal.

Dalam penelitian ini strategi crossword puzzle digunakan sebagai strategi pembelajaran peninjauan kembali, dugunakan untuk memberi tugas kepada peserta didik agar siswa dapat mengerjakan crossword puzzle sambil mengingat dan meninjau kembali materi dan konsep yang telah didapat sebelumnya.

Teka-teki silang dapat digunakan sebagai setrategi pembelajaran yang baik dan menyenangkan tanpa kehilangan esensi belajar yang sedang berlangsung. Bahkan strategi ini dapat melibatkan partisipasi peserta didik secara aktif sejak awal. Adapun crossword puzzle memiliki beberapa manfaat dan kekurangan.

Beberapa kekuarangan crossword puzzle diantaranya:

a. Peserta didik dituntut untuk berkonsentrasi secara matang;

b. Banyak memakan waktu dalam mengisi teka-teki silang;

c. Persiapan materi pembelajaran yan akan disampaikan guru harus matang.

Ghanoe dalam Ami Fatwayani (2013: 17) menguraikan beberapa manfaat dari pembelajaran dengan crossword puzzle antara lain:

a. Dapat mengasah daya ingat

Ketika teka-teki disodorkan, peserta didik akan menyisir semua pengalaman-pengalamannya hingga waktu itu, selanjutnya ia akan memilih-milih semua pengalamannya itu sekiranya cocok 
(sesuai) untuk menjawab teka-teki yang ada. Dengan demikian, manfaat teka-teki sebagai pengasah daya ingat telah didapatkan oleh seorang peserta didik.

b. Belajar klasifikasi

Hanya jenis teka-teki yang meminta jawaban terkait golongan yang diminta, sesmisal nama tempat, nama seseorang atau istilah-istilah lainnya. Ketika peserta didik disodori teka-teki tersebut, maka seorang peserta didik juga mendapatkan kesempatan untuk beradu pengetahuan dengan lawan mainnya.

c. Mengembangkan kemampuan analisa

Hampir semua jenis teka-teki memilikinya. Ketika sebuah pertanyaan disodorkan, peserta didik akan mengulas kembali seluruh pengalannya dan menganalisis pengalaman-pengalaman itu. Mana yang cocok untuk menjawab dan makna yang cocok untuk berargumentasi terhadap jawaban yang dipilihnya.

d. Menghibur

Ketika peserta didik sedang diberi teka-teki untuk dijawab, secara tidak langsung ia akan melupakan ingataningatan tertentu. Jika peserta didik cerdas misalnya, kecemasan itu akan terganti dengan kesibukannya dalam mencari jawaban dari teka-teki yang ada.

e. Merangsang kreativitas

Secara tidak langsung peserta didik juga akan dibantu teka-teki untuk menyalurkan potensi-potensi kreatifitas yang dimilikinya. Di dalam mempertahankan jawaban mislanya, peserta didik akan belajar berargumentasi, memilih bahasa yang mudah dipahami orang lain dan mencari cara-alternatif untuk menjawab. Tidak jarang ketika mancari jawaban soal, seorang peserta didik akan menemukan pertanyaan-pertanyaan baru yang belum tentu didapat sebelumnya.

b. Langkah-Langkah

Pembelajaran

Crossword Puzzle

Adapun langkah-langkah pembelajaran crossword puzzle adalah sebagai berikut:

1. Tulislah kata-kata kunci, terminologi atau nama-nama yang berhubungan dengan materi kuliah yang telah anda berikan;

2. Buatlah kisi-kisi yang dapat diisi dengan kata-kata yang telah dipilih (seperti dalam teka-teki silang). Hitamkan bagian yang tidak diperlukan;

3. Buat pertanyaan yang jawabannya adalah kata-kata yang telah dibuat atau dapat juga hanya membuat pertanyaanpertanyaan mengarah kepada kata-kata tersebut;

4. Bagikan teka-teki ini kepada peserta didik. Bias individu atau kelompok;

5. Batasi waktu mengerjakan;

6. Beri hadiah kepada kelompok atau individu yang mengerjakan cepat dan benar (Zaini, 2008:71)

Sedangkan dalam Melvin L. Silberman (2016: 256) ada beberapa prosedur dalam melakukan pembelajaran dengan menggunakan teka-teki silang, adapun prosedur tersebut sebagai berikut:

1. Langkah pertama adalah dengan menjelaskan beberapa istilah atau nama-nama penting yang terkait dengan mata pelajaran yang telah anda ajarkan.

2. Susunlah sebuah tela-teki silang sederhana, dengan menyertakan sebanyak mungkin unsur 
pelajaran. (jika terlalu sulit untuk membuat teka-teki silang tentang apa yang terkandung dalam pelajaran, sertakan unsurunsur yangbersifat menghibur, yang tidak mesti berhubungan dengan pelajaran sebagai selingan).

3. Susunlah kata-kata pemandu pengisian teka-teki silang anda. Gunakan jenis yang berikut ini:
a) Definisi singkat ("sebuah tes untuk menentukan reliabilitas")
b) Sebuah kategori yang cocok dengan unsurnya ("jenis gas")
c) Sebuah contoh ("....undang-undang adalah contohnya")
d) Lawan kata ("lawab kata demokrasi")

4. Bagikan teka-teki itu kepada siswa, baik secara perseorangan maupun kelompok.

5. Tetapkan batas waktunya. Berikan penghargaan kepada individu atau tim yang paling banyak memiliki jawaban benar. Dalam menerapkan teka-teki silang dalam pembeajaran bisa mengarahkan peserta didik untuk berperan aktif terhadap proses pembelajaran yang dilakukan. Proses pembelajaran dengan menggunakan teka-teki silang dapat dilakukan variasi agar pembelejaran tidak menjadi terkesan membosankan. Adapun variasi ini menurut Melvin L. Silberman adalah sebagai berikut:

1) Perintahkan seluruh kelompok untuk bekerjasama dalam mengisi teka-teki silang tersebut.

2) Sederhanakan teka-teki silang itu dengan menetapkan satu kata yang merupakan kunci dari pelajaran. Tuliskan dalam kotak mendatar. Gunakan kata yang menunjukkan unsurunsur lain dalam pelatihan dan cocokan secara menurun agar membentuk kata kunci (Mel. Silberman, 2007).

c. Kelebihan dan kelemahan strategi Crossword Puzzle

Kelebihan dari strategi crossword puzzle, antara lain:

a. Peserta didik lebih mudah untuk diajak selalu aktif dalam mengkoordinasikan

keterampilan tangan, mata dan kecepatan berpikir secara bersamaan.

b. Crossword puzzle bermanfaat untuk mengasah otak, melatih koordinasi mata, tangan, nalar dan kesabaran sehingga akan memudahkan proses pentransferan pengetahuan kepada para peserta didik.

c. Crossword puzzle memudahkan peserta didik dalam mengingat materi pelajaran yang disampaikan oleh guru.

d. Crossword Puzzle dapat meningkatkan

kemampuan berpikir untuk membuat peserta didik belajar berkonsentrasi.

e. Crossword Puzzle dapat menghilangkan rasa bosan karena mereka harus berpikir tentang jawaban sampai selesai.

f. Crossword Puzzle dapat 
melatih logika (Lyna

Rosyidah, 2012).

Sedangkan kelemahan dari strategi ini yaitu penggunaan waktu yang cukup banyak serta dapat menimbulkan sedikit kesulitan bagi peserta didik yang kurang akan tingkat kemampuannya dan kurang akan minat serta partisipasinya dalam proses pembelajaran

Pada dasarnya strategi crossword puzzle atau teka-teki silang adalah strategi pembelajaran untuk meninjau ulang materi-materi yang telah disampaikan. Peninjauan ulang materi ini dilakukan pada akhir pembelajaran. Peninjauan ini berguna untuk memudahkan peserta didik dalam mempertimbangkan informasi dan menemukan cara-cara untuk menyimpannya dalam otak. Strategi ini dapat membantu memudahkan peserta didik dalam belajar karena dalam strategi crossword puzzle atau teka-teki silang peserta didik tidak hanya belajar melainkan bisa bermain.

\section{Tinjauan Civic Knowledge}

Pendidikan kewraganegaraan mengembangkan 3 komponen pokok sebagai kompetensi peserta didik agar memiliki civic knowledge (pengetahuan kewarganegaraan), civic values/dispositions (nilai/karakter kewaganegaraan), civic skill (keterampilan kewarganegaraan). Pembagian atas ketiga domain ini jika dikaitkan dengan model Benjamin S Bloom maka akan tampak kesejajaranya dengan tiga ranah pembelajaran: kognitif, afektif dan psikomotor. Pengtehauan kewarganegaraan (civic knowledge) bisa disejajarkan dengan ranah kognitif, keterampilan/kecakapan kewarganegaraan (civic skill) sejajar dengan ranah psikomotor, sedangkan sikap/watak kewarganegaraan (civic disposition) sejajar dengan ranah afektif. "Civic knowledge adalah merupakan pengetahuan kewarganegaraan berkaitan dengan kandungan atau isi apa saja yang seharusnya diketahui oleh warga negara" (Winarno \& Wijianto, 2010: 51).

$$
\text { Cholisin (2004: }
$$

mengemukakan bahwa pengetahuan kewarganegaraan (civic knowledge) merupakan materi substansi yang harus diketahui oleh warga Negara. Pada prinsipnya pengetahuan yang harus diketahui oleh warga Negara berkaitan dengan hak-kewajiban /peran sebagai warga Negara dan pengetahuan yang mendasar tentang struktur dan system politik, pemerintahan dan system sosial yang ideal sebagaimana terdokumentasi dalam Pancasila dan UUD 1945, maupun yang telah menjadi konvensi dalam kehidupan berbangsa dan bernegara serta nilai-nilai universal dalam masyarakat demokratis serta cara-cara kerjasama untuk mewujudkan kemajuan bersama dan hidup berdampingan secara damai dalam masyarakat internasional.

\section{Pengetahuan}

kewarganegaraan (civic knowledge) berkaitan dengan kandungan yang seharusnya diketahui oleh warga negara. Sedangkan civic knowledge yang dimaksud adalah kemampuan yang dimiliki individu warga negara dalam aspek pengetahuan tentang ilmu kewarganegaraan. Baik di dalam National Standards dan Civic Framework for the 1998 National Assesment of Educational Progress (NAEP) (Branson, 1999: 9).

$$
\text { Branson (1999: }
$$
mengemukakan isi civic knowledge untuk konteks pengajaran di 
Indonesia diwujudkan dengan 5 pertanyaan sebagai berikut:

1) Apa kehidupan kewarganegaraan, politik dan pemerintahan?;

2) Apa fondasi-fondasi sistem politik ?;

3) Bagaimana pemerintahan yang dibentuk oleh konstitusi

mengejewantahkan tujuan-tujuan, nilai-nilai dan prinsip-prinsip demokrasi ?;

4) Bagaimana hubungan antara suatu negara dengan negara-negara lain di dunia ?;

5) Apa peran warga negara dalam demokrasi?

\section{B. METODE PENELITIAN}

Metode penelitian yang digunakan adalah kuasi eksperimen dengan desain penelitian Nonequivalent Control Group Design. Populasi pada penelitian ini adalah peserta didik SMA Negeri 3 Subang kelas XI tahun ajaran 2017/2018, dengan sampel adalah kelas XI IPA 1 sebagai kelas kontrol dan kelas XI IPA 4 sebagai kelas eksperimen. Sampel diambil dengan cara purposive sampling dari 10 kelas diambil 2 kelas, yaitu kelas eksperimen menggunakan model pembelajaran Think Pair Share (TPS) dengan strategi Crossword Puzzle dan kelas kontrol menggunakan pembelajaran konvensional. Instrumen penelitian yang digunakan adalah instrument tes berupa soal-soal pilihan ganda sebanyak 25 soal. Instrumen diolah menggunakan Software Minitab 17 for Windows.

\section{PEMBAHASAN}

Pembelajaran

yang dilaksanakan berjalan sesuai dengan rencana yang telah ditentukan, walaupun terdapat kekurangan dan kelemahan yang terjadi. Jika dilihat kembali dalam latar belakang diketahui bahwa permasalahan yang terjadi adalah tidak semua peserta didik mampu memahami materi yang diajarkan oleh guru. Selanjutnya, ketika guru membentuk kelompok banyak peserta didik pasif dan tidak ikut berpartisipasi dalam kelompoknya sehingga hanya peserta didik tertentu saja yang aktif dalam kegiatan kelompok. Selain itu sebagian peserta didik merasa malas dalam mengerjakan soal mata pelajaran PPKn yang sebagian besar soalnya bermuatan teoritis. Hal ini berdampak pada hasil belajar yang kurang optimal. Hal tersebut terjadi karena pembelajaran yang belum dapat dikembangkan dengan model pembelajaran yang menyenangkan untuk belajar. Oleh karena itu untuk meningkatkan civic knowledge peserta didik diterapkanlah model pembelajaran think pair share dengan strategi crossword puzzle. Sebelum perlakuan diberikan untuk mengetahui kemampuan awal peserta didik maka diberikan tes awal, dan berikut adalah rata-rata nilainya.

Tabel. 1

Perbandingan Rata-Rata Nilai

Pretest Kelas Eksperimen dan Kelas Kontrol

\begin{tabular}{|l|c|}
\hline \multicolumn{1}{|c|}{ Kelas } & $\begin{array}{c}\text { Rata-Rata } \\
\text { Nilai Pretest }\end{array}$ \\
\hline Eksperimen & 58.42 \\
\hline Kontrol & 57.49 \\
\hline
\end{tabular}

Berdasarkan Tabel 1 rata-rata nilai pretest kedua hampir sama. Keduanya berasal dari data nilai yang homogen atau sama.

Kemudian dengan melihat data hasil posttest, dapat diketahui 
civic knowledge peserta didik kelas eskperimen lebih baik dibandingkan kelas kontrol. hal tersebut terjadi karena peserta didik kelas eksperimen lebih banyak memahami materi melalui fase-fase pembelajaran dan juga peserta didik lebih aktif. Ratarata nilai posttest dapat dilihat dalam table dibawah ini :

Tabel 2

Perbandingan Rata-Rata Nilai

Posttest Kelas Eksperimen dan Kelas Kontrol

\begin{tabular}{|l|c|}
\hline \multicolumn{1}{|c|}{ Kelas } & $\begin{array}{c}\text { Rata-Rata } \\
\text { Nilai Pretest }\end{array}$ \\
\hline Eksperimen & 77.12 \\
\hline Kontrol & 71.91 \\
\hline
\end{tabular}

Dari tabel diatas diketahui rata-rata nilai dari kedua kelas adalah berbeda, yaitu kelas eskperimen memperoleh nilai 77.12 lebih tinggi dibandingkan kelas kontrol yaitu 71.91. Jadi dapat disimpulkan pembelajaran dalam kelas eksperimen lebih meningkatkan civic knowledge dibandingkan dengan pembelajaran di kelas kontrol. Berikut adalah grafik perbandingan civic knowledge kelas eksperimen dan kelas kontrol.

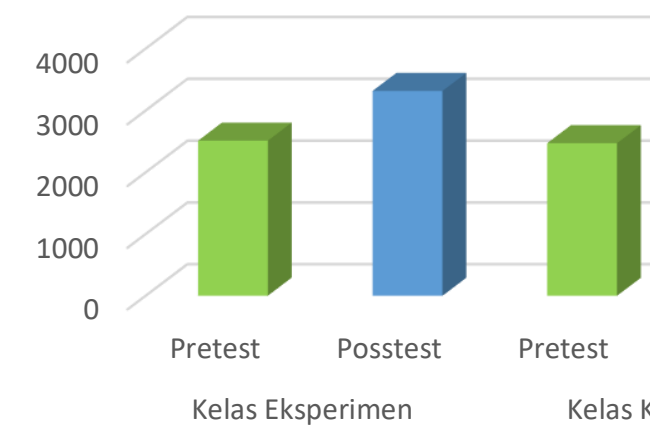

\section{Gambar 1 \\ Perbandingan Civic Knowledge \\ Peserta Didik \\ Kelas Eksperimen dan Kelas Kontrol}

Keberhasilan kelas eksperimen terjadi karena adanya pengaruh dari model pembelajaran think pair share. Berikut ini adalah kelebihan think pair share menurut Aris Shoimin (2014: 211) (1) TPS mudah diterapkan di berbagai jenjang pendidikan dan dalam setiap kesempatan, (2) Menyediakan waktu berpikir untuk meningkatkan kualitas respons peserta didik, (3) Peserta didik menjadi lebih aktif dalam berberpikir mengenai konsep dalam mata pelajaran, (4) Peserta didik lebih memahami tentang konsep topik pelajaran selama diskusi, (5) Peserta didik dapat belajar dari siswa lain. (6) Setiap siswa dalam kelompoknya mempunyai kesempatan untuk berbagi atau menyampaikan idenya.

Pada tahapan mengerjakan soal teka-teki silang peserta didik sangat antusias sekali karena mereka merasa sangat tertantang untuk mengisi kolom-kolom pertanyaan yang tersedia. Hal ini ditinjau dari perasaan senang, perhatian, keterlibatan peserta didik dalam pembelajaran dan ketertarikan peserta didik, sehingga melalui pengisian kosa kata dalam crossword puzzle membantu daya serap pembelajaran dan penguasaan konsep-konsep materi pada mata pelajaran PPKn. Dari hasil penelitian menunjukkan bahwa soal teka-teki silang memberikan alternatif kemudahan kepada peserta didik untuk mengerjakan soal. Ditinjau dari hasilnya dari pertemuan pertama sampai ketiga seluruh peserta didik dapat menjawab seluruh pertanyaan dengan benar.

Berdasarkan pemaparan data dan penjelasan di atas dapat ditarik kesimpulan bahwa hasil belajar merupakan salah satu ukuran yang sering kali dijadikan sebuah acuan bahwa peserta didik telah melalui proses pembelajaran. Oleh karena itu hasil belajar sangat ditentukan dari 
pengetahuan peserta didik yang didapat selama proses pembelajaran. Pengetahuan yang diperoleh dari sebuah proses belajar yang ditunjukkan dengan nilai tes atau angka nilai yang diberikan oleh guru. Oleh karena itu jika peserta didik mendapatkan hasil belajar yang rendah secara tidak langsung dapat diketahui bahwa peserta didik juga belum sepenuhnya memenuhi tujuan pembelajaran.

Dari permasalahan tersebut ditemukan salah satu alternatif pembelajaran yaitu dengan mengembangkan model-model pembelajaran. Model pembelajaran pada hakikatnya dapat membantu guru dalam mengkomunikasikan informasi, pengetahuan, keterampilan dan pengalaman kepada peserta didik lebih menarik untuk mencapai tujuan pembelajaran dengan suatu rencana atau pola yang dipersiapkan dengan baik (Nurul Insani, 2015). Model pembelajaran yang dipilih dalam penelitian ini yaitu model pembelajaran think pair share.

Selain model pembelajaran, faktor yang dapat mendukung proses pembelajaran adalah penggunaan strategi. Pembelajaran crossword puzzle dapat diterapkan sebagai salah satu strategi di dalam pembelajaran seperti yang dikemukakan Zaini dalam Reny Radili (2012) Teka-teki dapat digunakan sebagai strategi pembelajaran yang baik dan menyenangkan tanpa kehilangan esensi belajar yang sedang berlangsung.

Dengan penerapan model dan strategi tersebut diharapkan peserta didik lebih tertarik dengan materi pembelajaran karena suasana belajar yang menyenangkan, menambah motivasi dalam belajar dan juga tentunya menambah pengetahuan kewarganegaraan peserta didik. Selain itu juga mdel ini dapat meningkatkan tanggungjawab, kemampuan berkomunikasi, dan sikap saling menghargai antar sesama.

Pada penelitian ini kelas yang diteliti adalah kelas XI IPA 1 dan XI IPA 4. Kelas eksperimen atau kelas yang diberi perlakuan adalah klas XI IPA 4 dan XI IPA 1 sebagai kelas kontrol. Kelas XI IPA 1 terdiri dari 43 peserta didik dan kelas XI IPA 4 ini terdiri dari 43 peserta didik. Pada kelas XI IPA 1 dijadikan kelas kontrol dengan diberi perlakuan pendekatan saitifik sesuai dengan kebijakan Kurikulum 2013 bahwa setiap proses pembelajaran dilakukan dengan pendekatan konvensional, dan pembelajaran pada kelas XI IPA 4 ini dilaksanakan dengan menggunakan model pembelajaran think pair share dengan strategi crossword puzzle. Model pembelajaran think pair share (berpikir, berpasangan, berbagi) merupakan model pembelajaran yang dapat memicu keaktifan peserta didik. Selain itu crossword puzzle atau dalam Bahasa Indoensia dikenal dengan istilah teka-teki silang, dapat digunakan sebagai strategi pembelajaran yang baik dan menyenangkan tanpa kehilangan esensi belajar yang sedang berlangsung. Bahkan strategi ini dapat melibatkan partisipasi peserta didik secara aktif sejak awal.

Penelitian ini dilakukan di SMA Negeri 3 Subang yang berada di Jalan Emo Kurniaatmaja No 1 Kelurahan Pasirkareumbi Subang Jawa Barat. Sebelum melakukan penelitian, peneliti mencari informasi terdahulu mengenai instrument yang telah dibuat untuk menyesuaikan apakah instrument tersebut sesuai atau valid dengan apa yang dipelajari di kelas yang akan diteliti. 
Pada tanggal 23 Agustus dilaksanakan uji coba istrumen terhadap kelas atas sebanyak 1 kelas. Instrumen yang akan diuji cobakan ada sebanyak 50 soal dengan pilihan ganda. Berdasarkan uji validitas dengan menggunakan ANATES, diketahui dari 50 soal tersebut hanya 25 soal saja yang dapat digunakan (lampiran C.1).

Pokok bahasan yang akan diajarkan adalah mengenai sistem hukum dan peradilan nasional dengan 8 kali pertemuan yaitu 4 kali pertemuan termasuk pretest dan posttest di kelas eksperimen. Dan 4 kali pertemuan termasuk pretest dan posttest di kelas kontrol. Jadwal mata pelajaran PPKn pada kelas eksperimen dan kelas kontrol yaitu pada hari Rabu, kelas eksperimen pukul 07.00 - 08.30 dan kelas kontrol pukul 14.00 - 15.30. Masing-masing pertemuan untuk satu kali pertemuan ialah 90 menit.

Pada tanggal 30 Agustus mulai dilaksanakannya penelitian pertama dikelas eksperimen dan kelas kontrol dengan memberikan soal pretest dilanjutkan dengan mengajarkan materi yang telah dipersiapkan. Pemberian pre-test ini untuk mengetahui tingkat kemampuan peserta didik pada pembelajaran awal. Peserta didik diberi soal pre-test satu persatu untuk dikerjakan secara close book. Setelah pre-test dilaksanakan, dilanjutkan dengan menjelaskan.

Berdasarkan hasil analisis skor rata-rata pretest pengetahuan peserta didik, diperoleh kesimpulan bahwa kelas eksperimen dan kelas kontrol memiliki kemampuan awal yang sama. Kelas eksperimen memperoleh rata-rata sebesar 58,42 dengan standar deviasi 9,96. Sedangkan untuk kelas kontrol rata- rata nilai pretest yang diperoleh 57,49 dengan standar deviasi 8,77. Dengan demikian, terlihat bahwa civic knowledge antara kelas eksperimen dan kelas kontrol relatif sama.

Kondisi lingkungan belajar pada saat pertama kali pertemuan sangan tidak kondusif, karena peneliti langsung memberikan soal pretest sehingga banyak yang dari mereka mengeluh pada soal-soal yang diberikan karena banyak materi yang belum diajarkan. Terutama ketika di kelas kontrol banyak sekali peserta didik yang mengeluh dan pada jam pelajaran PPKn ini merupakan jam pelajaran terakhir sehingga banyak dari peserta didik yang sudah tidak kondusif.

Pada saat pelaksanaan pembelajaran di kelas eksperimen dengan menerapkan model pembelajaran think pair share suasana kelas sudah mulai dapat terkendali, hal tersebut diakarenakan pada model think pair share para peserta didik sibuk mendiskusikan pertanyaan-pertanyaan yang diberikan guru. Meskipun peserta didik sibuk dengan diskusi tidak banyak pula dari mereka yang membicarakan hal di luar materi, hal ini terait diskusi yang digunakan adalah diskusi pasangan sehingga diskusi yang dilaksanakan sedikit menyimpang, waktu yang diberikan untuk berdiskusi adalah sebanyak 25 menit.

Dalam pelaksanaanya, pembelajaran think pair share peserta didik menjadi beberapa kelompok yang beranggotakan 2 orang atau dengan kata lain berpasangan sesuai dengan namanya pair (berpasangan), sehingga peserta didik dapat lebih focus dan terkontrol sehingga memudahkan mereka untuk bekerja sama, begitu pula disaat persentasi, 
tiap anggota pasangan tidak saling mengandalkan dan pemahaman materi tidak hanya pada satu anggota saja, tetapi setiap pasangan dapat memahami materi tersebut. Dengan model think pair share peserta didik saling berinteraksi baik dengan teman maupun dengan guru. Dengan kegiatan interaksi tersebut, dapat meningkatkan , motivasi, kemampuan berkomunikasi, kemampuan berpikir kritis serta saling menghargai. Hal seperti inilah yang menjadikan civic knowledge (pengetahuan kewarganegaraan) peserta didik meningkat.

Meski model ini memberikan peningkatan terhadap civic knowledge peserta didik, akan tetapi masih terdapat kelemahan disaat pelaksanaannya. Hal ini dibuktikan dengan kelompok yang terbentuk sangat banyak sehingga waktu yang disediakan untuk persentasi tidak mencukupi dan tidak setiap pasangan dapat mempersentasikan jawaban mereka. Selain itu pada tiap tahapan pun terdapat kelemahannya, pada proses think pair share peserta didik cenderung mengulur-ulur waktu untuk menyelesaikan tugas yang diberikan dengan beberapa alasan sehingga tahap ini suasana kelas cukup ramai. Pada tahap pair peserta didik diminta untuk mendiskusikan jawaban dengan pasangannya, akan tetapi masih banyak dari mereka yang berbincang mengenai hal di luar materi pelajaran. Dan pada tahap share tiap pasangan ingin mempresentasikan terlebih dahulu, padahal waktu yang tersedia sedikit.

Pada tahap share banyak dari pasangan yang ingin mengungkapkan hasil jawaban mereka, namun waktu yang tersedia untuk persentasi hanya sedikit. Peneliti kesulitan dalam mengoptimalkan alokasi waktu. Hal ini juga menjadi salah satu kelemahan model pembelajaran think pair share. Selain itu pada pertemuaan ke-1 alokasi waktu pembelajaran terpotong oleh pengerjaan soal pretest sehingga peneliti pun menunjuk beberapa pasangan untuk mempersentasikan jawaban mereka. Waktu yang diberikan untuk mempersentasikan jawaban adalah sebanyak 5 menit untuk tiap-tiap pasangan. Waktu yang diberikan cukup sedikit, hal ini mengingat akan dilanjutkannya tahapan evaluasi yaitu dengan memberikan soal teka-teki silang atau crossword puzzle.

Pada tahapan mengerjakan soal teka-teki silang peserta didik sangat antusias sekali karena mereka merasa sangat tertantang untuk mengisi kolom-kolom pertanyaan yang tersedia. Hal ini ditinjau dari perasaan senang, perhatian, keterlibatan peserta didik dalam pembelajaran dan ketertarikan peserta didik, sehingga melalui pengisian kosa kata dalam crossword puzzle membantu daya serap pembelajaran dan penguasaan konsep-konsep materi pada mata pelajaran PPKn.

Keaktifan dan pengetahuan peserta didik dapat meningkat bila dilakukan suatu pembelajaran yang efektif dan efesien yaitu menggunakan model atau strategi pembelajaran yang bisa meningkatkan aktivitas peserta didik dalam pembelajaran. Guru bukan hanya menyampaikan pembelajaran tetapi guru harus bisa menciptakan suasana peserta didik yang aktif sehingga terjadi kseimbangan dipihak guru maupun peserta didik. Oleh sebab itu guru perlu melakukan variasi dalam strategi pembelajaran yang diterapkan dalam proses belajar mengajar di kelas sesuai dengan kebutuhan peserta didik dan 
kurikulum yang berlaku saat ini. Menurut Zaini, dkk (2008: 71) crossword puzzle dapat digunakan sebagai strategi pembelajaran yang baik dan menyenangkan tanpa kehilangan esensi belajar yang sedang berlangsung. Bahkan strategi ini dapat melibatkan partisipasi peserta didik secara aktif sejak awal. Meski strategi ini memberikan minat kepada peserta didik, akan tetapi masih terdapat kelemahan disaat pelaksanaannya. Hal ini dibuktikan sebagian besar mengerjakan penugasan teka-teki silang dengan sungguh-sungguh. Akan tetapi, kelemahannya peserta didik menjadi agak ribut ketika ada pertanyaan yang sulit. Sebagian kecil ada yang menoleh dan meminta jawaban kepada temannya.

Sehingga dapat disimpulkan bahwa strategi crossword puzzle mampu memotivasi antusias peserta didik, serta mengoptimalkan daya ingat peserta didik dalam belajar. Dapat dilihat dari kemampuanya mengingat pelajaran yang telah disampaikan selama pembelajaran dan bagaimana peserta didik tersebut bisa menerapkannya serta mampu memecahkan masalah yang timbul sesuai dengan apa yang telah dipelajari.

Untuk pertemuan-pertemuan selanjutnya kondisi kelas mulai berubah, dan kondisi peserta didik jauh lebih baik. Peserta didik mulai mengurangi kebiasaan mengobrol di luar materi pada saat pelaksanaan pembelajaran dengan model think pair share dengan strategi crossword puzzle. Di setiap pertemuan peneliti selalu menggunakan media berupa bagan agar peserta didik dapat lebih memahami dengan materi yang diajarkan dan untuk menarik minat peserta didik akan materi yang diajarkan. Pembelajaran berjalan dengan lancar sesuai dengan yang direncanakan karena kesulitan yang terjadi pada pertemuan pertama sudah dapat diantisipasi.

Sama halnya pada kelas kontrol, pertemuan pertama dilaksanakan pada tanggal 30 Agustus. Pertemuan pertama ini tidak berbeda jauh dengan kelas eksperimen. Pertemuan pertama ini peneliti memberikan soal pretest dan banyak dari mereka yang mengeluh akan tugas mengerjakan soal secara tiba-tiba ini. Peneliti memaklumi hal tersebut, terutama pada pertemuan pertama ini jam mata pelajaran PPKn berada pada akhir pelajaran, yang mana sebagaian besar dari peserta didik sudah mulai tidak kondusif untuk belajar. Selesainya mereka mengerjakan soal pretest peneliti mengajarkan dengan pendekatan konvensional sesuai dengan Kurikulum 2013. Oleh karena itu, tidak ada perbedaan jauh dengan kelas eksperimen yang mana kelas control ini sama-sama diberntuk kelompok hanya saja kelompok besar dengan jumlah peserta didik 4-5 orang dalam satu kelompok.

Pada kelas kontrol kesulitan yang dihadapi yaitu beberapa peserta didik tidak bekerjasama dalam kelompoknya. Dikarenakan dalam satu kelompok berjumlah 4-5 peserta didik, sehingga peserta didik yang aktif saja yang serius dalam mengerjakan tugas yang diberikan guru sementara peserta didik yang pasif hanya bermain-main saja. Kondisi kelas pada kelas kontrol cukup ramai, terutama pada peserta didik laki-laki. Tidak seperti pada kelas ekseprimen yang menggunakan model think pair share dengan strategi crossword puzzle kondisi kelas lebih kondusif. Hal tersebut 
memang dipengaruhi oleh beberapa faktor seperti penempatan jam pelajaran yang berbeda, seperti pada kelas eksperimen di jam pelajaran pertama yang mana kondisi fisik dan psikis peserta didik masih baik dan suasan kelas yang masih segar sehingga peserta didik lebih antusias dalam proses pembelajaran. Sementara sebaliknya pada kelas kontrol pada jam pelajaran terakhir yang mana kondisi fisik dan psikis peserta didik sudah kurang mendukung.

Setelah pembelajaran selesai dilakukan pada kedua kelas, pada tanggal 20 September peserta didik diberikan posttest untuk melihat peningkatan civic knowledge peserta didik kelas mana yang lebih baik. Dari posttest diperoleh rerata hasil posttest pada kelas eksperimen adalah 77.12. Sedangkan hasil posttest pada kelas kontrol adalah 71.91 secara deskriptif, hal ini menunjukan bahwa adanya peningkatan pada kelas eksperimen maupun kelas kontrol.

Berdasarkan hasil uji-t diperoleh bahwa perbedaan civic knowledge peserta didik kelas eksperimen lebih tinggi daripada kelas kontrol. Hal ini berdasarkan Gambar 4.12 dapat diperoleh nilai PValue 0,001. Nilai tersebut lebih kecil dari 0,05 , sehingga berdasarkan kriteria pengambilan keputusan $\mathrm{H}_{0}$ ditolak. Hal ini menunjukan bahwa civic knowledge peserta didik kelas eksperimen lebih tinggi daripada peserta didik kelas kontrol.

Kemudian dari hasil uji-t tersebut mendapatkan hasil bahwa ada pengaruh positif penggunaan model pembelajaran think pair share dengan strategi crossword puzzle terhadap civic knowledge peserta didik pada mata pelajaran pendidikan pancasila dan Kewarganegaraan di
SMA Negeri 3 Subang. Hasil pengujian nilai pretest dan posttest kelas eksperimen menunjukan bahwa nilai $\mathrm{P}$-Value $<0,05$ yaitu $0,000<$ 0,05 , sehingga $\mathrm{H}_{0}$ ditolak. Jadi dapat disimpulkan bahwa terdapat pengaruh yang signifikan model pembelajaran think pair share dengan strategi crossword puzzle terhadap civic knowledge peserta didik pada mata pelajaran pendidikan pancasila dan Kewarganegaraan di SMA Negeri 3 Subang.

Pembelajaran dengan menggunakan model pembelajaran think pair share dengan strategi crossword puzzle memberi pengaruh terhadap civic knowledge peserta didik. Hal ini terbukti pada kelas dengan pembelajaran think pair share dengan strategi crossword puzzle dapat menyelesaikan soal-soal lebih baik.

\section{KESIMPULAN}

Terdapat perbedaan yang signifikan civic knowledge peserta didik antara kelas eksperimen yang menggunakan model pembelajaran think pair share dengan strategi crossword puzzle dengan kelas kontrol yang menggunakan pedekatan konvensional. Ditinjau dari perhitungan uji-t posttest dengan taraf signifikansi 5\% diperoleh P-Value < 0,05 yaitu $0,003<0,05$. Hal tersebut diperoleh dari hasil posttest dengan nilai rata-rata kelas eksperimen yaitu 77.12 dan kelas kontrol yang mendapatkan nilai rata-rata 71.91.

Ada pengaruh positif penggunaan model pembelajaran think pair share dengan strategi crossword puzzle terhadap civic knowledge peserta didik pada mata pelajaran pendidikan pancasila dan Kewarganegaraan di SMA Negeri 3 Subang. Hasil pengujian nilai pretest 
dan posttest kelas eksperimen menunjukan bahwa nilai P-Value < 0,05 yaitu $0,000<0,05$, sehingga $\mathrm{H}_{0}$ ditolak. Jadi dapat disimpulkan bahwa terdapat pengaruh yang signifikan model pembelajaran think pair share dengan strategi crossword puzzle terhadap civic knowledge peserta didik pada mata pelajaran pendidikan pancasila dan Kewarganegaraan di SMA Negeri 3 Subang.

\section{E. DAFTAR PUSTAKA}

Anita, Lie. (2008). Cooverative Learning, Mempraktikan Cooverativve Learning di Ruang-Ruang Kelas. Jakarta: Grasindo

Arifin. (2009). Penelitian Pendidikan Metode dan Paradigma Baru. Bandung : Remaja Rosdakarya

Arikunto, Suharsimi. (2012). DasarDasar Evaluasi Pendidikan. Jakarta: Bumi Aksara

Branson, Margaret S, dkk. (1999). Belajar Civic Education dari Amerika. Yogyakarta: Kerjasama LKIS dan The Asia Foundation

Cholisin (2004). PPKn Paradigma Baru dan Pengembangannya dalam KBK, Jurnal Racmi, Media Informasi, Komunikasi, dan Pengembangan Sumberdaya, Volume 04 No. 01 Mei. Yogyakarta: Lembaga Penjamin Mutu Pendidikan (LPMP).

Darmadi, Hamid. (2013). Urgensi Pendidikan Pancasila dan Kewarganegaraan di Perguruan Tinggi. Bandung: Alfabeta

Dimyati dan Mujiono. (2002). Belajar dan Pembelajaran. Jakarta: Rineka Cipta
Djamarah, Syaiful Bahri dan Aswan Zain. (2010). Strategi Belajar Mengajar. Jakarta: Rineka Cipta

Isjoni. (2009). Cooperative Learning Efektivitas Pembelajaran Kelompok. Bandung: Alfabeta

Komalasari, Kokom. 2010. Pembelajaran Kontekstual, Konsep dan Aplikasi, PT. Refika Aditama, Bandung.

Maftuh, Bunyamin dan Sapriya. (2005). Pembelajaran PKn Melalui Pemetaan Konsep. Bandung: Jurnal Civicus. Jurusan PKn FPIPS UPI

Nasution. (2009). Metode Research. Jakarta: Bumi Aksara

Sa'dijah, Cholis. 2006. Penerapan Pembelajaran Kooperatif Think Pair Share TPS Malang: Lembaga Penelitian UM

Sapriya, Maftuh Bunyamin. (2005). Jurnal Civicus: Implementasi KBK Pendidikan Kewarganegaraan dalam Berbagi Konteks. Bandung : Jurusan PMPKn FPIPS

Slavin, Robert E. (2008). Cooperative Learning Teori, Riset, dan Praktik. Bandung: Nusa Media

Somantri.(2001). Menggagas Pembaharuan Pendidikan IPS. Bandung: PT. Remaja Rosda Karya

Sugiyono. (2016). Statistika untuk Penelitian. Bandung: Alfabeta

Trianto. (2007). Mendesain Model Pembelajaran InovtifProgresif. Surabaya. Kencana Prenada Media Group

UU Sisdiknas, (2003). UU RI No. 20 Tahun 2003. Jakarta : Sinar Grafika

Winarno, (2013). Pembelajaran Pendidikan Kewarganegaraan. Jakarta: PT Bumi Aksara 